\title{
Journal of Prosthodontic Research
}

\author{
Official Journal of Japan Prosthodontic Society
}

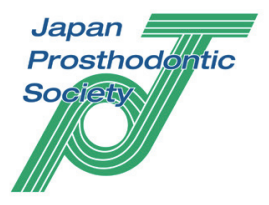

Review

\section{A potential application of materials based on a polymer and CAD/CAM composite resins in prosthetic dentistry}

\author{
Milica Jovanović*, Miloš Živić, Marko Milosavljević \\ Department of Dentistry, Faculty of Medical Sciences, University of Kragujevac, Kragujevac, Serbia
}

\begin{abstract}
Purpose: A bioactive high performance polymer (BioHPP) and computer-aided design/computer-aided manufacturing (CAD/CAM) composite resin materials are a relatively new class of dental biomaterials, that are biocompatible and have good aesthetic features. In this review paper, we will summarize literature and publication data on the characteristics of the mentioned materials, as well as their potential application in the dental prosthetics.

Study selection: Available studies and literature reviews from PubMed, SCIndex, Scopus and Google Scholar corresponding to polyetheretherketone (PEEK), high-performance polymers, reinforced composite materials, composite materials, resins, glass-fiber reinforced materials, CAD/CAM materials, dental implants, removable and fixed dental were reviewed.

Results: To avoid many disadvantages of metals and their alloys in dental practice, such as inadequate color, high density, thermal conductivity and possible allergic reactions, materials based on polymers (such as BioHPP), and CAD/CAM composite resins are being developed. These materials have significantly better aesthetics and physical-mechanical properties. They are biocompatible materials that are lightweight, resistant, durable, exhibit high bending and compression resistance.

Conclusions: The use of CAD/CAM composite resin materials and BioHPP in dentistry has begun recently, so the data about their potential clinical use are limited. Most of their features have been demonstrated through laboratory testing, while clinical studies are relatively scarce, so the need for further clinical trials is emphasized.

Keywords: Polymers, PEEK, BioHPP, Resins, CAD/CAM
\end{abstract}

Received date: 30 July 2019 , Accepted date: 13 August 2020, J-STAGE Advance published date: 26 September 2020

\section{Introduction}

Reconstruction of lost and caries-destroyed dental tissues, restoration of the original function and achievement of maximum aesthetic performance are the primary goals in dentistry [1]. It is essential to use materials of excellent mechanical and physical characteristics that will meet these requirements. The gold standard in prosthetics is a combination of precious and base metal alloys and ceramics, owing to their good mechanical and aesthetical properties [2]. Precious metals such as gold are relatively well tolerated in the oral cavity. However, the combination of different metals in the mouth, and the dissolution of metal ions in the saliva can cause galvanic corrosion, thereby compromising their biocompatibility [3,4]. Even for titanium, which is known to be corrosion-resistant, the study of Foti et al. proved that, in the state of polymetalism, titanium can corrode [5]. Study of Fretwurst et al. showed that titanium can be the reason for increased inflammatory response in peri-implant tissue [6]. Due to the

\footnotetext{
* Corresponding author at: Department of Dentistry, Faculty of Medical Sciences, University of Kragujevac, Svetozara Markovića 69, 34000 Kragujevac, Serbia.

E-mail address: micamonro@gmail.com (M. Jovanović).

https://doi.org/10.2186/jpr.JPOR_2019_404

1883-1958/C 2020 Japan Prosthodontic Society. All rights reserved.
}

disadvantages of metal alloys, such as unmatching colors of the teeth and dental tissues, thermal and electrical conductivity, high weight and density, potential allergenicity and relatively long processing time, there is an increasing number of studies examining materials with certain advantages over the traditional metal-ceramic restorations [710]. This primarily refers to materials with outmatching characteristics, biomechanical properties similar to the natural dentition, biomorphism, and a possibility of reparation [1,9]. Such material are glass-ceramics (particularly heat pressed glass-ceramics), crystalline ceramics (alumina), polycrystalline (alumina and zirconia) ceramics and various types of resins and polymers $[11,12]$. Due to the limited application of pressed ceramics, and frequent cracking of porcelain layers in zirconia ceramics [13], the latest studies have examined a new class of biomaterials, belonging to a large group of resin-based materials and polymers, that are glass-fiber or ceramics reinforced. They are computer-aided design/computer-aided manufacturing $(\mathrm{CAD} / \mathrm{CAM})$ composite resin materials, as well as polymer based on polyetheretherketone (PEEK), such as BioHPP (Bioactive High Performance Polymer) [14-18]. A reinforcement of resin materials with glass-fibers or ceramics significantly improves their mechanical and functional-aesthetic characteristics and their biological tolerance [1]. The results of individual studies have shown that resin materials can evenly distribute chewing loads and absorb a part of the applied load [19]. The use of CAD/CAM composite resins and BioHPP in dentistry 
has begun recently, so the data and researches about their characteristics and possible clinical use are ongoing. Although these two groups of materials differ in structure, they have the same way of processing in dentistry by CAD/CAM machine, and some of their indications in prosthetic dentistry intertwine. The aim of this review is to summarize the available literature data on the properties of BioHPP and CAD/ CAM composite resin materials, and on their potential application in the prosthetic rehabilitation of patients, with certain demarcations related to their physical-mechanical properties.

\section{Materials and methods}

In this paper, we reviewed studies from the period of 1999. to 2020. and had to meet the following criteria: clinical cases, clinical reports, experimental studies, and review articles related to Trinia, BioHPP (PEEK), Lava Ultimate, Cerasmart, Block HC, Brilliant Crios, Vita Enamic and other reinforced resin materials for CAD/CAM. The studies with material properties inadequately described, letters to editors, personal opinions and studies of limited accessibility were excluded from this paper. A search of published studies was conducted electronically, through the following databases: MEDLINE (Pubmed), Serbian Citation Index (SCIndex), Scopus and Google Scholar respectively, for the keywords: PEEK, polyetheretherketone, high-performance polymers, reinforced composite material, fiber reinforced composite material, glass fiber reinforced composite material, resins, CAD/CAM materials, dental implant, removable dental, fixed dental (Fig. 1). Table 1 summarizes the data from all experimental and clinical studies with full text access, that are involved in this paper.

\section{PEEK and modified PEEK - BioHPP}

BioHPP is a part of PEEK family, which is a relatively new material in a group of high-temperature thermoplastic and high-performance polymers. The original PEEK belongs to the polyketone family of aromatic polymers, with a semi-crystalline linear structure [20]. The chemical structure of PEEK $\left(-\mathrm{C}_{6} \mathrm{H}_{4}-\mathrm{OC}_{6} \mathrm{H}_{4}-\mathrm{O}-\mathrm{C}_{6} \mathrm{H}_{4}-\mathrm{CO}-\right)_{\mathrm{n}}$ [20] makes it extremely stable at high temperatures with melting point is about $335^{\circ} \mathrm{C}$. That is the reason why this material was interesting and useful in the industry [3,21]. Its tensile strength is about $80 \mathrm{MPa}$ [21], while the density of PEEK is $1300 \mathrm{~kg} / \mathrm{m}^{3}$ [20].

At the end of the $1990 \mathrm{~s}$, this material was commercialized in orthopedic surgery and traumatology where it was used to replace metal implant structures [22]. The validity of the application of PEEK for the manufacture of various implants lies in its outstanding physical and chemical properties.

PEEK is a tooth-colored material [21] with high purity and elasticity (Young `s elastic modulus is about 3-4 GPa), similar to those of human bone [23]. It is radiolucent, non-corrosive, non-toxic, non-allergenic, and stable to heat and sterilization. It is resistant to hydrolysis and shows good biocompatibility [23]. Another thing that is also important for its application in implant technology is its low water sorption rate and small solubility. This fact was demonstrated by Lieberman et al. [24]. An in vitro study showed that PEEK has the smallest solubility in physiological saliva $\left(0.33 \pm 0.11 \mu \mathrm{g} / \mathrm{mm}^{3}\right)$ compared with materials based on polymethyl methacrylate $\left(0.99 \pm 0.37-1.41 \pm 0.24 \mu \mathrm{g} / \mathrm{mm}^{3}\right)$ and composite resin $\left(0.84 \pm 0.4 \mu \mathrm{g} / \mathrm{mm}^{3}\right)$. Same is true for water absorption where the PEEK $(6.5$ $\left.\mu \mathrm{g} / \mathrm{mm}^{3}\right)[15]$ absorbed $<50 \%$ less water than resins $\left(10.6-18.8 \mu \mathrm{g} / \mathrm{mm}^{3}\right)$ [24,25]. Also, flexural strength about $170.37 \pm 19.31 \mathrm{MPa}$ [26] and high modulus of elasticity of 3-4 GPa [23] may alleviate the possibility of the material from breaking, and give it a consistency similar to the bone [27].

Due to its excellent physical and biological properties, in addition to other medical applications, PEEK is also used in dentistry for making implants, provisional abutments, implant-supported bar, clamp material in

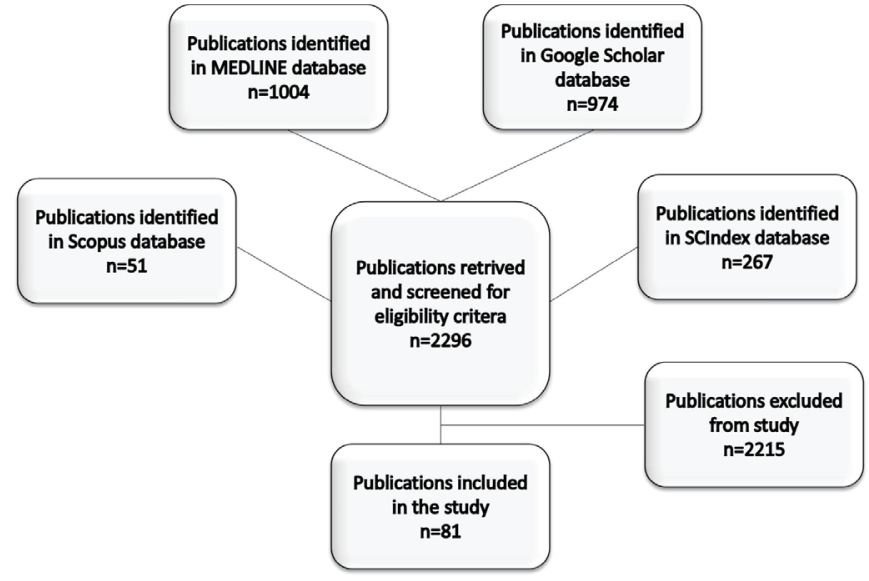

Fig. 1. Selection of studies.

the field of removable dental prostheses (RDPs) or fixed prosthodontics [28].

There are two ways of processing PEEK in dentistry. One way of manufacturing is milling from CAD/CAM blocks, and the other is vacuum pressing (pressing from granules or pellets). It should be emphasized that the way of processing can affect the mechanical properties and fracture load of PEEK, and the restoration made from this material [28]. So, the research of Stawarczyk et al. showed that industrial pre-pressing of blocks, such as CAD/CAM or pellet blocks, increased the mechanical properties and reliability of PEEK restorations [29].

Another good feature of PEEK and related to PEEK based materials is a low plaque affinity. This feature was also confirmed by Hahn et al. in their research, stating that the formation of dental biofilm on the PEEK surface is equal or even lower than other prosthetic materials, such as titanium and zirconia ceramics [30].

Although PEEK is fairly resilient to fracture load, there have been studies showing that this material is mechanically relatively weak in a homogeneous form, as shown by Tannous et al. [31]. They proved in vitro that clasps made of the cobalt-chromium (Co-Cr) alloy showed significantly higher retention force than PEEK. To improve the mechanical properties and bioactivity of PEEK, scientists have investigated possible combinations with other materials.

By adding $20 \%$ of a special ceramic filler to PEEK, a bioactive thermoplastic high-performance polymer-BioHPP is obtained [32]. This polymer has recently been modified by Bredent (BioHPP, Bredent, $\mathrm{GmbH}$, Senden, Germany) solely for use in dentistry. The size of ceramic particles in BioHPP is about 0.3 to 0.5 microns, which results in a consistent homogeneity in the polymer structure and thus optimizes its mechanical properties [32].

The elasticity modulus of BioHPP is similar to PEEK. It is about 4 $\mathrm{GPa}$, which is quite close to the elasticity of the human bone (like in mandible) [15]. Because of this, BioHPP can be useful in implantology, as it can reduce stress in the occurrence of the force of twisting. It can also stimulate bone remodeling around the implant. Having in mind a good biological tolerance of high-performance polymer, Wesley and Özcan described a potential application of BioHPP in the production of implants and abutments, as an alternative to titanium [33]. Its good biological tolerance was also suggested by Koutouzis et al. [34]. In a controlled clinical trial, they showed no increased risk of marginal bone loss and soft tissue recession, when applying polymer healing abutments, compared to titanium, during the initial healing period [34].

BioHPP exhibits the property of poor solubility in water, $<0.3 \mu \mathrm{g} /$ $\mathrm{mm}^{3}$, and the value of water absorption is about $6.5 \mu \mathrm{g} / \mathrm{mm}^{3}$ [15]. The properties of poor solubility in water and poor reactions with other materials can also be used in prosthetic dentistry for restorations 
Table 1. Overview of included studies, types of studies, used materials and therapeutic modalities.

\begin{tabular}{|c|c|c|c|c|c|}
\hline $\begin{array}{l}\text { Publication } \\
\text { ID }\end{array}$ & $\begin{array}{l}\text { Study } \\
\text { design }\end{array}$ & Study question (problem) & $\begin{array}{l}\text { Number } \\
\text { of cases }\end{array}$ & Material used & $\begin{array}{l}\text { Therapeutic } \\
\text { modality or } \\
\text { method of } \\
\text { use }\end{array}$ \\
\hline $\begin{array}{l}\text { Passaretti et al. } \\
2018[1]\end{array}$ & Clinical & Prosthetic rehabilitation of edentulous mandible & NR* & $\begin{array}{l}\text { Bicon implants and } \\
\text { Trinia (FRC) }\end{array}$ & $\begin{array}{l}\text { Fixed prosthesis } \\
\text { on short } \\
\text { implants }\end{array}$ \\
\hline $\begin{array}{l}\text { Merk et al. } \\
2016[3]\end{array}$ & Experimental & $\begin{array}{l}\text { Retention load between } \mathrm{ZrO}_{2} \text { primary crowns } \\
\text { and secondary PEEK crowns }\end{array}$ & 90 crowns & $\begin{array}{l}\text { Zirconium dioxide and } \\
\text { PEEK }\end{array}$ & Double crowns \\
\hline $\begin{array}{l}\text { Keulemans et al. } \\
2009 \text { [8] }\end{array}$ & Experimental & $\begin{array}{l}\text { In vitro evaluation of the influence of fiber- } \\
\text { reinforcement on the fracture strength and } \\
\text { fatigue resistance of resin-based composites }\end{array}$ & $\begin{array}{l}100 \\
\text { rectangular } \\
\text { bar-shaped } \\
\text { specimens }\end{array}$ & $\begin{array}{l}\text { PFC, FRC, } \\
\text { PFC and FRC combined }\end{array}$ & $\begin{array}{l}\text { Rectangular } \\
\text { bar-shaped } \\
\text { specimens }\end{array}$ \\
\hline $\begin{array}{l}\text { Başaran et al. } 2013 \\
\text { [9] }\end{array}$ & Experimental & $\begin{array}{l}\text { Comparison of the load bearing capacity of } \\
\text { fiber-reinforced and unreinforced CAD/CAM } \\
\text { fabricated fixed dental prostheses }\end{array}$ & 38 & $\begin{array}{l}\text { FRC and Experimental } \\
\text { FRC }\end{array}$ & $\begin{array}{l}\text { Fixed dental } \\
\text { prosthesis }\end{array}$ \\
\hline
\end{tabular}

$\begin{array}{ll}\text { Cekic-Nagas at al. Experimental } & \begin{array}{l}\text { Determination of the effect of hydro-fluoric acid } \\ \text { on in vitro micro-shear bond strength of resin }\end{array}\end{array}$ $2016[12]$ cement system to ceramics

\section{8}

specimens
VITA Enamic, LAVA $\quad 1,5 \mathrm{~mm}$ thick

Ultimate, Cerasmart

speciments

\begin{tabular}{|c|c|c|c|c|c|c|}
\hline & & & & & & micro-shear bond strength \\
\hline $\begin{array}{l}\text { Erkmen et al. } \\
2011[14]\end{array}$ & Experimental & $\begin{array}{l}\text { Comparison of implant retained fixed partial } \\
\text { dentures with metal and fiber reinforced } \\
\text { composite frameworks }\end{array}$ & 2 models & Metal and FRC & $\begin{array}{l}\text { Fixed partial } \\
\text { dentures }\end{array}$ & $\begin{array}{l}\text { FRC showed better load } \\
\text { distribution and less load- } \\
\text { bearing stress on structures and } \\
\text { tissue }\end{array}$ \\
\hline $\begin{array}{l}\text { Bechir et al. } \\
2016[15]\end{array}$ & Clinical & $\begin{array}{l}\text { Advantages of BioHPP } \\
\text { polymer as superstructure on implants }\end{array}$ & $\begin{array}{l}35 \text { patients, } \\
17 \\
\text { females and } \\
18 \text { males }\end{array}$ & $\begin{array}{l}\text { Modified PEEK - } \\
\text { BioHPP }\end{array}$ & $\begin{array}{l}\text { Framework } \\
\text { for fixed } \\
\text { prosthetic } \\
\text { restoration }\end{array}$ & $\begin{array}{l}\text { BioHPP showed good } \\
\text { biocompatibility, mechanical } \\
\text { characteristics and good } \\
\text { adaptation for patients }\end{array}$ \\
\hline $\begin{array}{l}\text { Bonfante et al. } \\
2015[16]\end{array}$ & Experimental & $\begin{array}{l}\text { Evaluating of the probability of survival, } \\
\text { strength characteristics and failure modes of } \\
\text { CAD/CAM FRC }\end{array}$ & 108 implants & FRC & $\begin{array}{l}\text { Implant } \\
\text { substructures }\end{array}$ & $\begin{array}{l}\text { There was no difference } \\
\text { between } 12 \mathrm{~mm}^{2} \text { and } 3 \mathrm{~mm}^{2} \text {, } \\
\text { but difference in failure modes } \\
\text { were detected }\end{array}$ \\
\hline $\begin{array}{l}\text { Biris et al. } \\
2017[17]\end{array}$ & Clinical & Using Trinia for abutments on Bicon implants & $\begin{array}{l}24 \text { patients, } \\
15 \text { females } \\
\text { and } 9 \text { males }\end{array}$ & Trinia & $\begin{array}{l}\text { Implant } \\
\text { abutments }\end{array}$ & $\begin{array}{l}\text { Trinia showed good mechanical } \\
\text { characteristics and good } \\
\text { adaptation for patients }\end{array}$ \\
\hline $\begin{array}{l}\text { Biris et al. } \\
2018[18]\end{array}$ & Clinical & $\begin{array}{l}\text { Usage of BioHPP and Trinia resins as core in } \\
\text { fixed prosthetic rehabilitation }\end{array}$ & $\begin{array}{l}33 \text { patients, } \\
17 \text { females } \\
\text { and } \\
16 \text { males }\end{array}$ & BioHPP and Trinia & $\begin{array}{l}\text { Fixed dental } \\
\text { prosthesis }\end{array}$ & $\begin{array}{l}\text { BioHPP and Trinia both } \\
\text { showed expected good clinical } \\
\text { characteristics }\end{array}$ \\
\hline $\begin{array}{l}\text { Yousry et al. } \\
2018 \text { [23] }\end{array}$ & Experimental & $\begin{array}{l}\text { Evaluation of strength of CAD/CAM BioHPP } \\
\text { with veneering composite using two different } \\
\text { adhesives and two types of cements }\end{array}$ & $\begin{array}{l}40 \mathrm{CAD} / \\
\text { CAM blocks }\end{array}$ & BioHPP (PEEK) & Veneers & $\begin{array}{l}\text { Share-bond strength between } \\
\text { BioHPP and dentin is better } \\
\text { when using Fuji plus (resin } \\
\text { reinforced glass ionomer) }\end{array}$ \\
\hline $\begin{array}{l}\text { Lieberman et al. } \\
2016[24]\end{array}$ & Experimental & $\begin{array}{l}\text { Effects of different aging regimens/durations on } \\
\text { roughness, solubility, water absorption, Martens } \\
\text { hardness (HM), and indentation modulus/EIT on } \\
\text { different CAD/CAM polymers }\end{array}$ & $\begin{array}{l}40 \\
\text { specimens }\end{array}$ & $\begin{array}{l}\text { PEEK, LAVA Ultimate } \\
\text { and other }\end{array}$ & $\begin{array}{l}\text { Standardized } \\
\text { specimens }\end{array}$ & $\begin{array}{l}\text { The hardness parameters of } \\
\text { PEEK showed no statistical } \\
\text { difference comparing to } \\
\text { PMMA-based materials }\end{array}$ \\
\hline $\begin{array}{l}\text { Misilli et al. } \\
2017[25]\end{array}$ & Experimental & $\begin{array}{l}\text { Comparison of the degree of water sorption } \\
\text { and solubility in bulk-fills after curing with a } \\
\text { polywave light source }\end{array}$ & $\begin{array}{l}120 \\
\text { specimens }\end{array}$ & $\begin{array}{l}\text { Voco, Ivoclar Vivadent, } \\
\text { Kerr and 3M ESPE }\end{array}$ & $\begin{array}{l}\text { Disc-shaped } \\
\text { specimens }\end{array}$ & $\begin{array}{l}\text { Water sorption and solubility } \\
\text { values are affected by the } \\
\text { filler ratio and type of resin } \\
\text { matrix, regardless of the } \\
\text { composite type }\end{array}$ \\
\hline $\begin{array}{l}\text { Schwitalla et al. } \\
2015 \text { [26] }\end{array}$ & Experimental & $\begin{array}{l}\text { Evaluation of the mechanical properties of } \\
\text { different commercial PEEK compounds via } \\
\text { three-point-bending tests }\end{array}$ & $\begin{array}{l}150 \\
\text { specimens }\end{array}$ & PEEK & Bars & $\begin{array}{l}\text { In comparison to the prevailing } \\
\text { minimum strength for plastic } \\
\text { materials their superiority is } \\
\text { evidently presented by the } \\
\text { characteristic of maintaining } \\
\text { their stability despite alternating } \\
\text { temperature changes }\end{array}$ \\
\hline $\begin{array}{l}\text { Siewert et al. } \\
2013[27]\end{array}$ & Clinical & $\begin{array}{l}\text { Usage of PEEK as a framework material for } \\
\text { removable dental prosthesis }\end{array}$ & 2 patients & PEEK & $\begin{array}{l}\text { Framework for } \\
\text { a dental bridge }\end{array}$ & $\begin{array}{l}\text { BioHPP showed good } \\
\text { mechanical characteristics and } \\
\text { biocompatibility }\end{array}$ \\
\hline
\end{tabular}

Trinia could be material of

choice when there is possibility for fixed denture on implants

In assessing retention load,

PEEK may be a suitable

material for removable

prosthesis and telescopic crown technique when

used on zirconia crowns

FRC showed better

characteristics, fatigue

resistance and fracture

strength than PFC and its combination with FRC

Experimental fiber-reinforced resin blocks had better load-

bearing capacities than unreinforced resin blocks

Hydro-fluoric acid does not affect on bond strength, but combination of resin cements and ceramic/glass-polymer materials significantly affect micro-shear bond strength

FRC showed better load

bearing stress on structures and

BioHPP showed good compatibility, mechanical characteristics and good adaptation for patients

iure modes

Trinia showed good mechanical characteristics and good

BioHPP and Trinia both showed expected good clinical

BioHPP and dentin is bette

hen using Fuji plus (resin

The hardness parameters of

PEEK showed no statistical

difference comparing to

Water sorption and solubility values are affected by the filler ratio and type of resin matrix, regardless of the In comparison to the prevailing minimum strength for plastic materials their superiority is characteristic of maintainin their stability despite alternating temperature changes biocompatibility 


\begin{tabular}{|c|c|c|c|c|c|c|}
\hline $\begin{array}{l}\text { Stock et al. } \\
2016[28]\end{array}$ & Experimental & $\begin{array}{l}\text { Assessment of retention forces of secondary } \\
\text { PEEK crowns }\end{array}$ & $\begin{array}{l}90 \\
\text { specimens }\end{array}$ & BioHPP (PEEK) & $\begin{array}{l}\text { Secondary } \\
\text { telescopic } \\
\text { crowns }\end{array}$ & $\begin{array}{l}\text { Milled PEEK crowns had } \\
\text { different retention based on } \\
\text { taper angle, while pressed } \\
\text { PEEK crowns had the same } \\
\text { retention force }\end{array}$ \\
\hline $\begin{array}{l}\text { Stawarczyk et al. } \\
2013 \text { [29] }\end{array}$ & Experimental & $\begin{array}{l}\text { Fracture load evaluation of fixed dental } \\
\text { prosthesis made of PEEK }\end{array}$ & $\begin{array}{l}45 \\
\text { specimens }\end{array}$ & PEEK & $\begin{array}{l}\text { Fixed dental } \\
\text { prosthesis }\end{array}$ & $\begin{array}{l}\text { PEEK/C reinforced with } \\
\text { other inorganic fillers can be } \\
\text { potentially used as crown and } \\
\text { bridge material }\end{array}$ \\
\hline $\begin{array}{l}\text { Hahnel et al. } \\
2014[30]\end{array}$ & Experimental & $\begin{array}{l}\text { Formation of biofilms on the surface of materials } \\
\text { applied for the fabrication of implant abutments }\end{array}$ & $\begin{array}{l}40 \\
\text { specimens }\end{array}$ & PEEK & $\begin{array}{l}\text { Implant } \\
\text { abutments }\end{array}$ & $\begin{array}{l}\text { Biofilm formation on the } \\
\text { surface of PEEK is equal or } \\
\text { lower than on the surface } \\
\text { of conventionally applied } \\
\text { abutment materials }\end{array}$ \\
\hline $\begin{array}{l}\text { Tannous et al. } 2011 \\
\text { [31] }\end{array}$ & Experimental & $\begin{array}{l}\text { Evaluation of the retentive force of clasps made } \\
\text { from three thermoplastic resins and cobalt- } \\
\text { chromium }(\mathrm{Co}-\mathrm{Cr}) \text { alloy }\end{array}$ & $\begin{array}{l}112 \\
\text { specimens }\end{array}$ & PEEK & Clasps & $\begin{array}{l}\text { Adequately designed PEEK } \\
\text { clasps might be sufficient for } \\
\text { clinical use, but had lower } \\
\text { retention than Co-Cr alloy }\end{array}$ \\
\hline $\begin{array}{l}\text { Koutouzis et al. } \\
2011[34]\end{array}$ & Clinical & $\begin{array}{l}\text { Evaluation of soft and hard tissue responses to } \\
\text { titanium and polymer healing abutments }\end{array}$ & 16 patients & PEEK & Abutments & $\begin{array}{l}\text { PEEK healing abutments had } \\
\text { lower risk for marginal bone } \\
\text { loss and soft tissue recession } \\
\text { than titanium }\end{array}$ \\
\hline
\end{tabular}

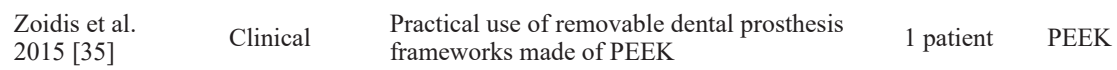

BioHPP should not be Removable $\quad$ framework material for a well2015 [35] Clinical frameworks made of PEEK $\quad 1$ patient PEEK dental prosthesis designed Co-Cr RPD, except frameworks in patient with taste sensitivity, allergies, additional periodontal support for teeth

\begin{tabular}{llllll}
\hline $\begin{array}{l}\text { Costa-Palau et al. } \\
2014[36]\end{array}$ & Clinical & $\begin{array}{l}\text { Practical use of PEEK for making maxillary } \\
\text { obturator prosthesis }\end{array}$ & 1 patient & PEEK & $\begin{array}{l}\text { Obturator } \\
\text { prosthesis }\end{array}$ \\
\hline $\begin{array}{l}\text { Andrikopoulou } \\
\text { et al. 2016 [38] }\end{array}$ & Clinical & Use of PEEK for fixed dental prosthesis & 1 patient & PEEK & $\begin{array}{l}\text { Fixed dental } \\
\text { prosthesis }\end{array}$ \\
\hline
\end{tabular}

Lucsanszky et al. 2020 [46]

Experimental

Comparison of the fracture toughness, flexural strength and flexural modulus
CERASMART, KZR-

CAD-HR2, CAMouflage CAD/CAM

NOW, Enamic Obsidian block

PEEK can be used in maxillofacial reconstructive therapy

BioHPP can be used as an alternative treatment option

Resin composite block materials had inferior flexural strength, flexural modulus and fracture toughness than Obsidian and inferior flexural modulus than Enamic

PICN showed more similar mechanical properties and biocompatibility to natural teeth comparing to common CAD/CAM blocks, except in brittleness index composites, LAVA Ultimate

Impregnated FRC possessed impact strength significantly lower than the preimpregnated E-glass FRC

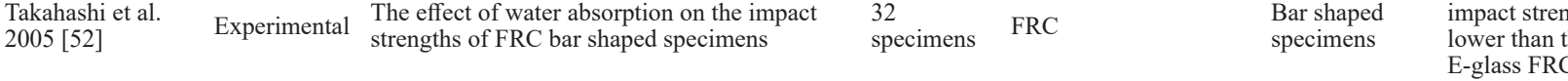

\begin{tabular}{llll}
\hline Ewers et al. & Clinical & $\begin{array}{l}\text { CAD/CAM planning and milling procedures } \\
\text { for treatment of extremely severe maxillary and } 101 \text { patients } \\
\text { mandibular atrophy }\end{array}$ & $\begin{array}{l}\text { Trinia } \\
\text { maj] }\end{array}$ \\
\hline
\end{tabular}

\begin{tabular}{lll} 
Seemann et al. Clinical & $\begin{array}{l}\text { Determination of the effectiveness of fixed, fiber- } \\
\text { reinforced resin bridges on ultrashort implants } \\
\text { with a sufficient implant survival success rate of } 10 \text { patients } \\
\text { at least } 90 \% \text { in highly atrophic jaws }\end{array} \quad$ Trinia \\
\hline
\end{tabular}

Fixed dental

This method is comparable to metal-ceramic restorations

\section{Resin bridges on ultrashort} implants have shown equivalent early implant survival rates relative to other single ultra short implants

16

Comparison of mechanical properties of resin-

Bassi et al.

$2016[55]$

Experimental bonded glass fiber-reinforced (TCFRA) and titanium abutments specimens (8 Epoxy resin reinforced

TCFRA and with glass fiber 8 titanium)
Abutments

TCFRA showed reduced stress on the bone-implant interface

Dental bridges retained by four ultra short implants provide a comparatively cost-effective, safe, and stable alternative for prosthetic restoration of the severely atrophic mandible
Framework fo superstructure on implants

$\begin{array}{lll}\text { Seemann et al. } & \text { Clinical } & \begin{array}{l}\text { Evaluation of midterm outcomes of fixed, full- } \\ \text { arch, fiber-reinforced resin bridges on ultrashort } 17 \text { patients Trinia } \\ \text { implants in terms of marginal bone loss and } \\ \text { overall implant survival }\end{array}\end{array}$

Spitznagel et al. $2020[60]$
Evaluation of clinical outcome of Vita Enamic,

Clinical $\mathrm{CAD} / \mathrm{CAM}$ manufactured single crowns after 3 years
PICN CAD/CAM crowns with reduced thickness showed acceptable survival and success rates over a service time of 36 months 


$\begin{array}{llll}\text { Alamoush et al. } 2018 \text { Experimental } & \begin{array}{l}\text { Evaluation of the composition of CAD/CAM } \\ \text { blocks and their mechanical properties }\end{array} & \begin{array}{l}168 \\ \text { specimens }\end{array} & \begin{array}{l}\text { Resin composite CAD/ } \\ \text { CAM blocks }\end{array}\end{array}$

Koizumi et al. 2015

[63]

Experimental

Evaluation of the gloss and surface roughness behaviors of newly developed CAD/CAM composite blocks with different filler content and characteristics

$\begin{array}{ll}30 & \text { LAVA Ultimate, } \\ \text { specimens } & \begin{array}{l}\text { Cerasmart, Shofu blok } \\ \text { and other }\end{array}\end{array}$

CAD/CAM composite

materials have comparable

hardness and modulus of elasticity to tooth structure

Significant difference in the gloss unit was detected between the Shofu Block

$\mathrm{HC}$ material and the ceramic

block after toothbrush abrasion

Tested materials had significantly higher flexural strength and modulus of resilience, along with lower flexural modulus values compared with the common ceramic or hybrid materials

The resin ceramics had lower modulus of elasticity and hardness than glass ceramics but had less wear than enamel and glass ceramics

Reinforced composite block should be used to fabricate monolithic crowns in the premolar area as it provided high fracture strength with the added advantage of easy intra-oral repair of the restoration when needed

PMMA based resin has been used to fabricate provisional CAD/CAM; Performance of PMMA was similar to VitaEnamic which is used for permanent single tooth restorations

Vita Enamic presented the lowest strength and highest Weibull modulus among the materials

Flexural strength of CAD

CAM materials was significantly decreased by artificial aging;

Cyclic loading or $\mathrm{HCl}$ exposure does not affect to the flexural strength and structural reliability of Cerasmart and

Lava Ultimate
Evaluation of the fatigue failure load, number of cycles until failure, and survival probability Venturini et al. 2019 Experimental of adhesively cemented materials with different 15 [73] microstructures (glass-, hybrid- and resinceramic) used to manufacture $\mathrm{CAD} / \mathrm{CAM}$ monolithic restorations
Feldspathic, leucite, lithium disilicate, zirconia-reinforced lithium silicate, polymer-infiltrated ceramic network and resin nanoceramic presented the best fatigue performance due to greater resilience, which enabled more stress absorption through deformation as the main outcome; while glassand hybrid ceramic materials showed brittleness and radial cracking as the main outcome

PICN with a reduced thickness of $1 \mathrm{~mm}$ appeared to be a reliable $\mathrm{CAD} / \mathrm{CAM}$ material for posterior crowns

Surface treatments resulted in higher surface roughness values compared to the control groups

Sandblasting significantly increases surface roughness values and microtensile bond strength of dual-cure adhesive cement of each CAD/CAM restorative 
Investigation of the influence of material,

Rosentritt et al. 2019 [77] fracture force of CAD/CAM resin composite molar crowns
Shofu Block HC, Lava

Ultimate, Grandio Blocs Crowns

and Tetric CAD
Fracture forces were not influenced by preparation but by the type of material Clinical success and debonding of $\mathrm{CAD} / \mathrm{CAM}$ resin composite crowns is strongly influenced by the type of material and its pre-treatment

RNC crowns luted to stock and customized zirconia implant abutments with the

Schepke et al. 2015 [80]

Clinical

Evaluation of new dental restorative bonding abutments
50 patients LAVA Ultimate and others particular resin composite cement in this trial have a poor prognosis, regardless of the abutment type used

Crowns

BI and marginal chipping are positively corelated, indicating that the $\mathrm{BI}$ of a material can be used as a predictor of the $\mathrm{CF}$
Tsitrou et al. 2007 [81]
Investigation of possible correlation between Expermental the brittleness index (BI) of machinable dental materials and the
10 Paradigm MZ100TM,

10 Vita Mark II, ProCAD, Crowns

\footnotetext{
* - Not Reported
}

in patients who are allergic to Co-Cr alloy or who are sensitive to metallic taste in conventional Co-Cr dentures [32].

This high-performance polymer can be used in fixed prosthetics for making crowns and bridges, especially for people suffering from parafunctional activities, such as bruxism. The polymer disables the abrasion of the antagonist teeth and withstands a load of chewing forces without any fractures [32]. In this context, fracture resistance obtained by in vitro tests is about $1200 \mathrm{~N}$, which, in comparison to the maximal chewing strength of $500 \mathrm{~N}$, represents an adequate safety limit. The flexural strength of this material is $>150 \mathrm{MPa}$ [15].

Owing to its natural tooth color and high strength, BioHPP can be used as an alternative material for removable partial dentures (RPDs) frames, for making metal-free clasps and occlusal rests [32]. The bond strength of BioHPP framework is over $25 \mathrm{MPa}$ [15]. In the development of classical RPD, due to the high elasticity of the alveolar ridges, under the occlusal load, the distally extended part of the prosthesis shows a higher degree of rotation around the support point, which can create a distal torque on the abutment teeth. Zoidis et al. applied a BioHPP frame RPD for the prosthetic rehabilitation of a patient with Kennedy I class in the lower jaw [35]. They used this material with an initial hypothesis that, due to its elasticity, it is possible to reduce the distal moment and the stress around the retention teeth. That showed a BioHPP's potential alternative use in the management of cases with distal extension, and teeth requiring additional periodontal support, taste sensitivity, and $\mathrm{Co}-\mathrm{Cr}$ allergies. Due to its low specific weight, a BioHPP denture is $27.5 \%$ lighter than RPDs with $\mathrm{Co}-\mathrm{Cr}$ alloy frameworks [35]. This gives a patient satisfaction and comfort while wearing the prosthesis.

Due to biocompatibility and low density of BioHPP, which is about 1.31 $\mathrm{g} / \mathrm{cm}^{3}$, this material is useful for a denture obturator [36]. An in vitro test study reports that good polishing of BioHPP with low surface roughness can be achieved either using dental instruments or instruments from dental technicians for the polishing process [37]. These tests show good resistance to abrasion and color stability. As these tests have only confirmed laboratory results, additional clinical research is needed to confirm the BioHPP properties. On the other hand, there is case research conducted by Andrikopoulou et al. reporting the use of the modified PEEK - BioHPP for the fabrication of resin-bonded fixed dental prosthesis framework in young cleft lip and palate patient [38]. It was concluded that BioHPP can't substitute the conventional metal-ceramic or all-ceramic materials, however, it can be an alternative treatment option, but further long-term clinical evidence is still needed [38].

\section{CAD/CAM composite resin materials}

One of the first studies examining the properties and application of glassreinforced composite materials in medicine emerged back in the 1960s [39]. Further studies related to the characteristics and new applications of these materials began in the 1990 s, following their increased application in dentistry [40].

On the other hand, the resin-based composites have been used in restorative dentistry for many years. A conventional resin system in dental composites includes dimethacrylates based on bisphenol A glycidyl methacrylate (BisGMA), urethane dimethacrylate (UDMA), and triethylene glycol dimethacrylate (TEGDMA) [41]. Among these systems, the maximal flexural strength of a homopolymer was found at UDMA, being $133.8 \mathrm{MPa}[42]$.

Due to insufficient mechanical characteristics, traditional resin composites are used mainly on anterior teeth or in smaller posterior restoration [43]. In cases of large posterior restorations, in cuspal replacements and patients with parafunctions, it is necessary to improve the mechanical properties of materials and reduce the polymerization shrinkage [44]. One way to improve their performance is through the industrial processing of resin composites using CAD/CAM technology.

Feldspathic ceramics had been used in $\mathrm{CAD} / \mathrm{CAM}$ restoration, but its use was reduced as new materials with better mechanical properties, such as leucite-reinforced porcelain and lithium-reinforced porcelain, developed [45]. Even though ceramic blocks provide superior mechanical properties, their disadvantages are a need for the firing process, hydrofluoric acid bonding, abrasiveness different from teeth, and brittleness $[12,45]$.

Aiming for the development of material with better characteristics than ceramics and glass ceramics, the production of resin CAD/CAM composite blocks had started. Owing to its composition and structure, $\mathrm{CAD} / \mathrm{CAM}$ composite resin materials have good esthetical and mechanical properties, such as firmness, flexibility, and durability [1,17]. Compared to metal alloys, it has biocompatibility, while its edge stability, excellent machinability, and reduced brittleness are its advantages, compared to ceramic/glass-ceramic blocks [46].

\subsection{CAD/CAM glass-fiber reinforced composite - Trinia}

Trinia (Shofu Dental Corporation, San Marcos, USA), a recently introduced indirect resin-based composite material, belongs to a group of glass-reinforced composite materials and is described as a 3D fiber reinforced composite (FRC), manufactured for CAD/CAM applications $[17,47]$. It is $60 \%$ glass fibers and $40 \%$ epoxy resin fabricated through 
several layers of multi-directional interlacing. Glass-fibers permeate resin layers and give the material the firmness similar to a thermally hardened thermoplastic plate $[17,18,48]$.

Trinia has a high flexural strength of $393 \mathrm{MPa}$ and compressive strength of $374 \mathrm{MPa}$ (parallel force) and $339 \mathrm{MPa}$ (transverse force) [17]. Another feature is its elasticity modulus, very similar to the dentin elasticity modulus, like other hybrid materials [49]. The elasticity modulus of dentin is $8,7-25 \mathrm{GPa}$, while Trinia is $18.8 \mathrm{GPa}[17,49,50]$. Fracture toughness and density of Trinia are $9.7 \mathrm{MPa} \mathrm{m} \mathrm{m}^{1 / 2}$ and $1.68 \mathrm{~g} / \mathrm{cm}^{3}$, respectively [51].

Aside from adequate strength and resistance to fractures, Trinia possesses a very low water absorption quality, which is about $0.03 \%$ $[51,52]$ and resilience that affects the mucous-bone fundament, comparable to Sharpey's fibers [53]. Trinia can be used to produce a large number of dental restorations such as inlays, onlays, crowns, bridges, veneers, as well as superstructures and supporting structures of dental restorations on implants $[16,48,53]$.

In the pilot study conducted by Seemana et al., Trinia was used as a framework material for the reconstruction of the lower dental arch, with 4 ultra-short implants implanted [54]. Using a metal-free, implant-supported, fixed prosthesis avoids extensive, laborious crafting of heavy metal parts in the restoration suprastructure. Using Trinia, CAD/CAM-milled bridges can withstand chewing forces with no fracture or chipping [54]. However, it is found that opposing dentures in 7 out of 10 patients, limit the bite force. It is necessary to conduct a study with the same problem but with more patients to confirm this conclusion. In a study conducted by Bassi et al., the effect of a force at a certain angle is compared to titanium made abutments and glass-fiber reinforced resins [55]. Glass-fiber reinforced resin abutments show a lower percentage of decementation (37.5\%), and no fracture or deformation of the material, while the decementation and fracture of titanium was $62.5 \%$ and $12.5 \%$ of cases respectively [55].

Biris et al. examined Trinia on the non-metal superstructure and Bicon implants [18]. Eighteen months after the embedding, cementing, and monitoring, it was found out that there were no signs of weakness in the material or fractures on Trinia superstructure or implants. Glass-fiber reinforced resin-based materials have an advantage compared to ceramics when it comes to restorations on implants, due to the lesser impact of the chewing force on the implants up to $50 \%[18,56,57]$.

A study by Passaretti et al. showed that the use of non-metal fixed restorations on implants avoids fracture of the restoration and implants due to the effect of chewing force distribution [1]. The authors also showed that due to the material properties, it was easier to accomplish highquality polishing, which reduces mucosal irritation and biofilm adhesion $[18,51,58]$.

Seemana et al., in their clinical study used Trinia to make superstructure on Bicon implants to treat the patient with atrophic mandible and concluded that fixed full-arch bridges, made from glass-fiber reinforced resins, retained by four ultrashort implants provide a comparatively costeffective, safe, and stable alternative for prosthetic restoration of the severely atrophic mandible [59].

One of the disadvantages of Trinia listed in the literature, as well as all materials reinforced with glass particles, is the possibility of mucous membrane irritation if in direct contact. Careful work is advisable while polishing the restorations made from this material [17].

\subsection{Other reinforced CAD/CAM composite resins}

Unlike Trinia, which contains fiber-glass, the second class of relatively new $\mathrm{CAD} / \mathrm{CAM}$ materials are resin-matrix ceramics $\mathrm{CAD} / \mathrm{CAM}$ materials. They combine superior aesthetic properties of ceramics and positive properties of nonbrittle composites and polymer. These materials can be divided according to microstructure and manufacturing process into two groups: ceramic particle-filled composites with dispersed fillers and polymer-infiltrated ceramic networks (PICNs) [60] (Table 2). The first group is the composites consisting of basic monomer type as organic matrix and dispersed fillers (zirconia, silica, barium glass). They are Lava Ultimate (LU) (3M ESPE, StPaul, MN, USA), Cerasmart (GC America, Alsip, IL, USA), Block HC (BHC) (Shofu Block HC, Shofu Inc., Kyoto, Japan) and Brilliant Crios (BC) (Colten, Switzerland) [61, 62-65]. The other group is PICN materials consists of porous ceramic scaffold structure which is infiltrated with monomer mixture, making the material less brittle than ceramics. VITA Enamic (VE) (Vita Zahnfabrik H. Rauter, Bad Säckingen, Germany) is one of the recently developed PICN material, called hybrid ceramic, and consists of feldspathic ceramic network $86 \%$ by weight, that is fully integrated with polymer network (14\% by weight) [66].

The LU material consists of $80 \%$ ceramic particles, and $20 \%$ composite resin, so it is called nano-ceramic resin [64]. Cerasmart is a nanoparticlefilled high-density composite resin, which contains $71 \%$ of filler particles by weight [65]. BHC from Shofu is composed of $61 \%$ by weight of silica powder, zirconium silicate, and micro-clustered silica particles in a resin matrix and it is available as blocks or discs for CAD/CAM milling [62]. $\mathrm{BC}$ is also a resin block that is reinforced with $70 \%$ of glass and amorphous silica [61].

Compared to Trinia, whose Young's modulus is closest to dentin, the specified CAD/CAM ceramic reinforced composite materials have slightly lower values of elastic modulus (Table 3) $[17,49,50,67,68]$. The elastic modulus of the material, which is near as in dentin, enables better load distribution on dentin rather than accumulating in restorations [68].

Flexural strength of LU and Cerasmart is examined in the study of Lawson et al. and is compared with glass-ceramic material (e.max CAD and Celtra Duo) showing a value of 248.4 MPa for LU and 234.5 MPa for Cerasmart [67]. Their results differ from a study in which flexural strength for LU (178 MPa) was significantly lower than for Cerasmart (219 $\mathrm{MPa}$ ) [65]. The value of flexural strength for LU, which is closer to the study of Lawson et al., was obtained in a study of Agarwalla et al., and its value was $201 \mathrm{MPa}$ [69]. Flexural strength for BC and BHC is $198 \mathrm{MPa}$ and $170 \mathrm{MPa}$, respectively $[47,65]$. The flexural strength of CAD/CAM composite resin materials is higher than that of conventional composite resin [70], probably because of the high filler load in CAD/CAM materials and factory polymerization, which involve heat and pressure [49]. Flexural strength values of CAD/CAM ceramic reinforced composites are lower than Trinia but are closer to BioHPP (>150 MPa) [17,20,47,65,67,68]. Lim et al. showed that VE had a flexural strength of about $108.7 \mathrm{MPa}$, lower than LU and direct composite material that was examined. They consider that porous feldspathic ceramic matrix, infiltrated in monomer in VE is responsible for the increased ability of the material to withstand mechanical stress by deforming elastically rather than fracturing. Also, they consider that the microstructure of LU, as well as, wider distribution of silica/zirconia particles increases the likelihood for crack deflection and increases flexural strength of this material [71].

However, Lucsanszky and Ruse tested flexural strength, flexural modulus, and fracture toughness of VE and Cerasmart related to lithium disilicate glass-ceramic blocks (Obsidian) and showed that VE and Cerasmart have lower values of examined parameters [46]. Also, they determined that flexural modulus for VE $(33.02 \mathrm{GPa})$ is higher than Cerasmart $(9.25 \mathrm{GPa})$, as well as, aging of materials have a significant impact on flexural strength leading to lowering this values, while it does not affect the flexural modulus.

Jassim and Majeed examined the values of flexural and fracture strength for monolithic crowns fabricated from BC, glass-ceramic materials (lithium disilicate and zirconia-reinforced lithium silicate) and hybrid ceramic (VE) [68]. They showed that the flexural strength of $\mathrm{BC}(198 \mathrm{MPa})$ and $\mathrm{VE}(150-160 \mathrm{MPa})$ is much lower than that of ceramic materials $(360 \mathrm{MPa}$ and $370 \mathrm{MPa})$, while the fracture strength is significantly higher for BC $(1880 \mathrm{~N})$ than ceramic materials $(1085$ $\mathrm{N}$ and $1404 \mathrm{~N})$. VE had the lowest value for fracture strength $(767 \mathrm{~N})$. Thus, they concluded that the chemical composition and microstructure 
Table 2. Composition and indication of examined polymers and CAD/CAM composite resin materials.

\begin{tabular}{|c|c|c|c|c|}
\hline Material & Filler particule $(\%)$ & Resin monomer & Manufacturer & Indication (by manufacturer) \\
\hline PEEK & l & $\begin{array}{c}\text { Aromatic polymer } \\
\text { (poly-ether-ether ketone) }\end{array}$ & / & $\begin{array}{l}\text { Dental implants, implant abutments, framework for RPDs, } \\
\text { fixed crowns and bridges }\end{array}$ \\
\hline BioHPP & $20 \%$ ceramic filler & $\begin{array}{c}\text { Polymer } \\
\text { (poly-ether-ether-ketone) }\end{array}$ & Bredent & Abutment, telescopic crowns, framework for RPDs \\
\hline Trinia & $60 \%$ glass-fiber & $40 \%$ epoxy resin & SHOFU & $\begin{array}{l}\text { Substructures or frameworks for permanent and transitional anterior or } \\
\text { posterior crowns, bridgework, telescopic restorations }\end{array}$ \\
\hline Lava Ultimate & $\begin{array}{c}80 \% \\
\mathrm{SiO}_{2}(20 \mathrm{~nm}), \mathrm{ZrO}_{2} \\
(4-11 \mathrm{~nm}), \\
\text { aggregated } \mathrm{ZrO} / \mathrm{SiO}_{2} \\
\text { cluster }\end{array}$ & $\begin{array}{l}\text { Bis-GMA, UDMA, } \\
\text { Bis-EMA*, TEGDMA }\end{array}$ & 3M ESPE & Inlays, onlays, veneers \\
\hline Cerasmart & $\begin{array}{c}71 \% \\
\text { silica }(20 \mathrm{~nm}), \text { barium glass } \\
(300 \mathrm{~nm})\end{array}$ & $\begin{array}{l}\text { Bis-MEPP**, UDMA, } \\
\text { DMA*** }\end{array}$ & GC Corporation & Inlays, onlays, crowns, veneers, implant- supported crowns \\
\hline Block HC & $\begin{array}{c}61 \% \\
\text { silica powder, } \\
\text { zirconium silicate, } \\
\text { micro-clustered silica }\end{array}$ & UDMA, TEGDMA & SHOFU & $\begin{array}{l}\text { Inlays, onlays, veneers, full crowns for anterior and posterior teeth, } \\
\text { implant- supported restorations }\end{array}$ \\
\hline Briliant Crios & $\begin{array}{c}70 \% \\
\text { glass and } \\
\text { amorphous silica }\end{array}$ & $\begin{array}{c}\text { Cross-linked } \\
\text { methacrylates } \\
\text { (Bis-GMA, Bis-EMA, } \\
\text { TEGDMA) }\end{array}$ & COLTENE & Inlays, onlays, crowns, veneers, implant-supported restorations \\
\hline VITA Enamic & $\begin{array}{l}86 \% \text { feldspathic } \\
\text { ceramic enriched with } \\
\text { aluminium oxide }\end{array}$ & UDMA, TEGDMA & Vita Zahnfabric & $\begin{array}{l}\text { Inlays, onlays, veneers, anterior and posterior crowns, anterior and } \\
\text { posterior crowns on implants }\end{array}$ \\
\hline
\end{tabular}

*Bis-EMA - ethoxylated bisphenol-A dimethacrylate

**Bis-MEPP - 2,2-Bis(4-methacryloxypolyethoxyphenyl) propane

***DMA - dimethacrylate

Table 3. Elastic (Young`s) modulus of CAD/CAM composite resins.

\begin{tabular}{ccc}
\hline Material & $\begin{array}{c}\text { Modulus of elasticity } \\
\text { (GPa) }\end{array}$ & References \\
\hline Dentin & $8.7-25$ & {$[50]$} \\
\hline Trinia & 18.8 & {$[17]$} \\
\hline Lava Ultimate & $12.77 \pm 0.99$ & {$[50]$} \\
\hline Cerasmart & $9.25-12.1$ & {$[46,66]$} \\
\hline Block HC & $7.2-9.6$ & {$[50]$} \\
\hline Briliant Crios & 10.3 & {$[68]$} \\
\hline VITA Enamic & $21.2-30.03$ & {$[46,67]$} \\
\hline
\end{tabular}

of the material had a significant impact on the fracture strength of thefabricated crowns. Nevertheless, in brittle materials, such as ceramics, the value of flexural strength should not be taken alone to indicate structural performance because material strength is conditional [68]. Since the fracture strength of all crowns exceeds the maximum biting force in the premolar region, they suggest that all tested materials could be successfully used clinically as monolithic crown restorations in the premolar region. A similar result of flexural strength for VE (150 MPa) was shown in the study of Agarwalla et al. [69]. In this study, it is also tested Weibull modulus (m) which is a material-specific parameter describing the scatter of strength as a result of flaws within the microstructure. The values that were obtained are 14.3 for VE and 13.5 for LU. In the study of Eglimez et al. that examined Weibull modulus after different in vitro aging conditions, values for VE and LU were similar and amounted between 9 to 19.09 according to aging conditions. For Cerasmart Weibull modulus was significantly lower and was in range 7-8 [72].

Venturini et al. in vitro evaluated fatigue performance of adhesively cemented glass-, hybrid- (VE) and resin-ceramic (LU) materials for CAD/ CAM monolithic restorations [73]. They showed that the microstructure of examined materials affects their performance under fatigue. Resinceramic material presented the best fatigue performance due to the greater resilience (survived until the last loading step $(2200 \mathrm{~N})$ and the number of cycles (100.000) without radial cracking, which enabled more stress absorption through deformation as the main outcome. Glass- and hybridceramic materials showed brittleness and radial cracking as the main outcome (all PICN specimens failed in the first step $(400 \mathrm{~N} ; 10,000)$ ) [73].

On the other hand, Giertmuehlen et al. analyzed the effect of the material thickness $(1.5 \mathrm{~mm}$ and $1.0 \mathrm{~mm})$ on fatigue behavior $(1.2$ million cycles, $198 \mathrm{~N}$ ) and failure load of monolithic PICN (VE) CAD/CAM molar crowns [74]. All PICN specimens survived fatigue exposure, and the conclusion is that PICN with thickness of $1.0 \mathrm{~mm}$ appeared to be a reliable $\mathrm{CAD} / \mathrm{CAM}$ material for posterior crowns.

Similar results were obtained in a controlled in vivo clinical trial conducted by Spitznagel et al. [60]. They evaluated the clinical outcomes of monolithic CAD/CAM PICN single crowns with a reduced thickness on premolar and molar teeth, after a 36-month observation period. This study concluded that PICN monolithic crowns showed acceptable survival and success rate after the observed time, but suggested extended clinical follow-up periods for long-term evaluation of material performance [60].

Papadopoulos et al. investigated the surface roughness and morphology of BHC, LU, BC, and VE using four different surface treatments [75]. The surface of the specimens of each material received sandblasting with 29 $\mu \mathrm{m} \mathrm{Al}_{2} \mathrm{O}_{3}$ particles, $9 \%$ hydrofluoric acid etching and silane application, and the tribochemical method using CoJet System. Also, they had control specimens of each material with no surface treatment. Compared to the control groups, surface treatments in all tested materials resulted in higher surface roughness values, but there were not negligible differences among the surface treatments. The influence of treatments to surface properties of the tested materials is probably due to discrepancies in their composition and structure [75]. Tekce et al. got similar results while investigated the effect of sandblasting power particles on microtensile bond strength of dual-cure adhesive cement (G-CEM LinkForce) to CAD/CAM materials (LU, VE, Cerasmart). They concluded that sandblasting significantly increased surface roughness values of investigated CAD/CAM materials [76].

The fields of application of CAD/CAM ceramic reinforced composites (LU, Cerasmart, BC, BHC) are generally similar, so they are used for inlays, onlays, crowns, and veneers [62]. Their application is more focused on minimally invasive dentistry, so in comparison to Trinia, it is limited in the field of implant superstructures, mainly as implant-supported single crown restoration. Due to a high de-bonding rate of LU, crown indication 
for this material is removed by the manufacturer (3M ESPE) in 2015. Since then, the indication for LU is restricted on inlays, onlays, and veneers [77].

The indications for PICN (VE) are similar to other CAD/CAM composite resin materials: minimally invasive restorations and posterior crowns, veneers, inlays, and onlays for posterior teeth and implantsupported crowns [78]. From this aspect of an application in prosthetics, Trinia is rather comparable to PEEK based materials. (Fig. 2). The main disadvantage associated with the use of these materials is that, to date, a sufficient number of clinical studies have been conducted to define the advantages and disadvantages of materials in clinical practice. This fact that the clinical short and long-term evidence is still scarce is highlighted in the paper of Spitznagel et al. [79]. The study conducted by Schepke et al. analyzed the bonding and performance of single implant restoration made of nanoceramic resin composite material (LU) to either zirconia stock abutments or zirconia customized implant abutments [80]. They concluded that the bond covered crowns and customized zirconia implant abutments with the particular resin composite cement have a poor prognosis, regardless of the abutment type used [80].

What distinguishes these materials from classic ceramics is a lower brittleness index and the chipping factor which is a direct indicator of the marginal degree of chipping. In the study of Tsitrou et al., CAD/CAM composite resins and ceramics were compared for the brittleness index and chipping factor. It was shown that a higher brittleness index is associated with a higher chipping factor. Due to a less brittle structure, ceramicreinforced composite resins are less sensitive to chipping when processed in thin dimensions [81].

\section{Conclusion}

BioHPP and CAD/CAM composite resin materials reinforced with glassfibers and ceramics are innovative biomaterials attracting interest for use in prosthetic dentistry. Based on the available literature data, we concluded that these materials offer many advantages over traditional metal-ceramic materials, such as better aesthetics properties, biocompatibility, and less brittleness. Also, the conclusion is that CAD/CAM composite resin materials have lower mechanical properties related to lithium disilicate glass ceramics, but superior to feldspathic ceramics. Summing up the available literature and publications we concluded that the best indication for using BioHPP and Trinia in prosthetics is making a framework for superstructure on implants. Other $\mathrm{CAD} / \mathrm{CAM}$ composite resin materials are useful for inlays, onlays, veneers, and full crowns, except for LU that is not suitable for full crowns. Further clinical studies are necessary to confirm the properties and a wider field of application of these materials.

\section{Conflict of interest}

There are no potential conflict of interest.

\section{References}

[1] Passaretti A, Petroni G, Miracolo G, Savoia V, Perpetuini A, Cicconetti A. Metal free, full arch, fixed prosthesis for edentulous mandible rehabilitation on four implants. J Prosthodont Res 2018;62(2):264-67. https://doi.org/10.1016/ j.jpor.2017.10.002

[2] Wataha JC. Alloys for prosthodontic restorations. J Prosthet Dent 2002;4:35163. https://doi.org/10.1067/mpr.2002.123817

[3] Merk S, Wagner C, Stock V, Eichberger M, Schmidlin PR, Roos M, et al. Suitability of secondary PEEK telescopic crowns on zirconia primary crowns: The influence of fabrication method and taper. Materials 2016;9(11):908. https://doi.org/10.3390/ma9110908

[4] Cortada M, Giner LL, Costa S, Gil FJ, Rodriguez D, Planell JA. Galvanic corrosion behavior of titanium implants coupled to dental alloys. J Mater Sci Mater Med 2002;5:287-93.

[5] Foti B, Tavitian P, Tosello A, Bonfil JJ, Franquin JC. Polymetallism and osseointegration in oral implantology: Pilot study on primate. J Oral Rehabil 1999;6:495-502. https://doi.org/10.1046/j.1365-2842.1999.00404.x

[6] Fretwurst T, Nelson K, Tarnow DP, Wang H-L, Giannobile WV. Is metal particle release associated with peri-implant bone destruction? An emerging concept. J Dent Res 2018;97(3):259-65. https://doi.org/10.1177/0022034517740560

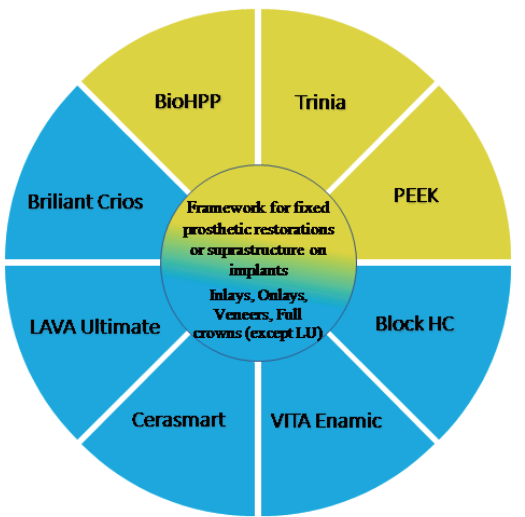

Fig. 2. The most common indications of PEEK, BioHPP, Trinia (yellow framework for fixed prosthetic restorations or superstructure on implants) and $\mathrm{CAD} / \mathrm{CAM}$ composite resin materials (blue - inlays, onlays, veneers, full crowns) in prosthetics.

[7] Van Heumen CC, Kreulen CM, Creugers NH. Clinical studies of fiberreinforced resin-bonded fixed partial dentures: a systematic review. Eur J Oral Sci 2009;117:1-6. https://doi.org/10.1111/i.1600-0722.2008.00595.x

[8] Keulemans F, Palav P, Aboushelib MM, van Dalen A, Kleverlaan CJ, Feilzer AJ. Fracture strength and fatigue resistance of dental resin-based composites. Dent Mater 2009;25:1433-41. https://doi.org/10.1016/j.dental.2009.06.013

[9] Başaran EG, Ayna E, Vallittu PK, Lassila LV. Load bearing capacity of fiberreinforced and unreinforced composite resin CAD/CAM-fabricated fixed dental prostheses. J Prosthet Dent 2013;109:88-94. https://doi.org/10.1016/S00223913(13)60022-0

[10] Ohlmann B, Bermejo JL, Rammelsberg P, Schmitter M, Zenthöfer A, Stober $\mathrm{T}$. Comparison of incidence of complications and aesthetic performance for posterior metal-free polymer crowns and metal-ceramic crowns: results from a randomized clinical trial. J Dent 2014;42:671-6. https://doi.org/10.1016/ j.jdent.2014.03.002

[11] Shenoy A, Shenoy N. Dental ceramics: An update. J Conserv Dent 2010;13(4):195-203. doi: 10.4103/0972-0707.73379.

[12] Cekic-Nagas I, Ergun G, Egilmez F, Vallittu PK, Lassila LV. Micro-shear bond strength of different resin cements to ceramic/glass-polymer CAD-CAM block materials. J Prosthodont Res 2016;60(4):265-73. https://doi.org/10.1016/ j.jpor.2016.02.003

[13] Pjetursson BE, Sailer I, Zwahlen M, Hämmerle CH. A systematic review of the survival and complication rates of all-ceramic and metal-ceramic reconstructions after an observation period of at least 3 years. Part I: single crowns. Clin Oral Implants Res 2008;18:73-85. https://doi.org/10.1016/S00223913(13)60022-0

[14] Erkmen E, Meric G, Kurt A, Tunc Y, Eser A. Biomechanical comparison of implant retained fixed partial dentures with fiber reinforced composite versus conventional metal frameworks: a 3D FEA study. J Mech Behav Biomed Mater 2011;4(1):107-16. https://doi.org/10.1016/i.jmbbm.2010.09.011

[15] Bechir ES, Bechir A, Gioga C, Manu R, Burcea A, Dascalu IT. The advantages of BioHPP polymer as superstructure material in oral implantology. Mater Plast 2016;53(3):394-8.

[16] Bonfante EA, Suzuki M, Carvalho RM, Hirata R, Lubelski W, Bonfante G, et al. Digitally produced fiber-reinforced composite substructures for threeunit implant-supported fixed dental prostheses. Int J Oral Maxillofac Implants 2015;30(2):321-9. https://doi.org/10.11607/jomi.3892

[17] Biris C, Bechir ES, Bechir A, Mola FC, Caraiane A, Badiu AV, et al. Trinia reinforced polymer as core for implants superstructure. Mater Plast 2017;54(4):764-7.

[18] Biris C, Bechir ES, Bechir A, Mola FC, Badiu AV, Oltean C, et al. Evaluations of two reinforced polymers used as metal-free substructures in fixed dental restorations. Mater Plast 2018;55(1):33-7.

[19] Ciftci Y, Canay S. Stress distribution on the metal framework of the implantsupported fixed prosthesis using different veneering materials. Int J Prosthodont 2001:14(5):406-11.

[20] Skirbutis G, Dzingutė A, Masiliūnaitė V, Šulcaitė G, Žilinskas J. A review of PEEK polymer's properties and its use in prosthodontics. Stomatologija 2017; 19:19-23.

[21] Najeeb S, Zafar MS, Khursid Z, Siddiqui F. Applications of polyetheretherketone (PEEK) in oral implantology and prosthodontics. J Prosthodont Res 2016;60:12-19. https://doi.org/10.1016/j.jpor.2015.10.001

[22] Kurtz SM, Devine JN. PEEK biomaterials in trauma, orthopedic, and spinal implants. Biomaterials 2007;28:4845-69. https://doi.org/10.1016/ j.biomaterials.2007.07.013

[23] Yousry MA, Hussein SA, Al Abbassy FH. Evaluation of shear bond strength of high-performance polymers to its resin veenering and to dentin (in vitro study). Alex Dent J 2018;43:62-8. 
[24] Liebermann A, Wimmer T, Schmidlin PR, Scherer H, Löffl er P, Roos M, et al. Physicomechanical characterization of polyetheretherketone and current esthetic dental CAD/CAM polymers after aging in different storage media. J Prosthet Dent 2016;115:321-8. https://doi.org/10.1016/i.prosdent.2015.09.004

[25] Misilli T, Gönülol N. Water sorption and solubility of bulk-fill composites polymerized with a third generation LED LCU. Brazil Oral Res 2017;31:e80 doi: 10.1590/1807-3107bor-2017.vol31.0080

[26] Schwitalla AD, Spintig T, Kallage I, Müller W-D. Flexural behavior of PEEK materials for dental application. Dent Mater 2015;31(11):1377-84 https://doi. org/10.1016/j.dental.2015.08.151

[27] Siewert B, Parra M. A new group of materials in dentistry. PEEK as a framework material for 12-piece implant-supported bridges. Z Zahnärztl Implantol 2013;29:148-59 [In German]. doi:10.3238/ZZI.2013.0148-0159

[28] Stock V, Wagner C, Merk S, Roos M, Schmidlin PR, Eichberger M, et al. Retention force of differently fabricated telescopic PEEK crowns with different tapers. Dent Mater J 2016;35(4):594-600. doi: 10.4012/dmj.2015-249.

[29] Stawarczyk B, Eichberger M, Uhrenbacher J, Wimmer T, Edelhoff D, Schmidlin PR. Three-unit reinforced polyetheretherketone composite FDPs: Influence of fabrication method on load-bearing capacity and failure types. Dent Mater J 2015;34:7-12. https://doi.org/10.4012/dmj.2013-345

[30] Hahnel S, Wieser A, Lang R, Rosentritt M. Biofilm formation on the surface of modern implant abutment materials. Clin Oral Implants Res 2014;26:1297-301. https://doi.org/10.1111/clr.12454

[31] Tannous F, Steiner M, Shahin R, Kern M. Retentive forces and fatigue resistance of thermoplastic resin clasps. Dent Mater 2012;28:273-8. https://doi. org/10.1016/j.dental.2011.10.016

[32] Georgiev J, Vlahova A, Kissov H, Aleksandrov S, Kazakova R. Possible application of BioHPP in prosthetic dentistry: a literature review. J IMAB 2018;24(1):1896-8. https://doi.org/10.5272/jimab.2018241.1896

[33] Wiesli MG, Özcan M. High performance polymers and their potential application as medical and oral implant materials: a review. Implant Dentist 2015;24(4):448-57. https://doi.org/10.1097/ID.0000000000000285

[34] Koutouzis T, Richardson J, Lundgren T. Comparative soft and hard tissue responses to titanium and polymer healing abutments. J Oral Implantol 2011;37:174-82. https://doi.org/10.1563/AAID-JOI-D-09-00102.1

[35] Zoidis P, Papathanasiou I, Polyzois G. The use of a modified poly-ether-etherketone (PEEK) as an alternative framework material for removable dental prostheses. A Clinical Report. J Prosthodont 2015;25(7):580-4. https://doi. org/10.1111/jopr.12325

[36] Costa-Palau S, Torrents- Nicolas J, Brufau-de Barberà M, Cabratosa-Termes J. Use of polyetheretherketone in the fabrication of a maxillary obturator prosthesis: a clinical report. J Prosthet Dent 2014;112(3):680-2. https://doi. org/10.1016/j.prosdent.2013.10.026

[37] Rzanny A, Gobel F, Fachet M: BioHPP summary of results for material tests Research Report. Jena, Germany, University of Jena, Department of Materials and Technology, 2013

[38] Andrikopoulou E, Zoidis P, Artopoulou II, Doukoudakis A. Modified PEEK resin bonded fixed dental prosthesis for a young cleft lip and palate patient. J Esthet Restor Dent 2016;28(4):201-7. https://doi.org/10.1111/jerd.12221

[39] Smith DC. Recent developments and prospects in dental polymers. J Prosthet Dent 1962:12:1066-78.

[40] Vallittu PK, Närhi TO, Hupa L. Fiber glass-bioactive glass composite for bone replacing and bone anchoring implants. Dent Mater 2015;31(4):371-81. https:// doi.org/10.1016/j.dental.2015.01.003

[41] Vallittu P, Matinlinna J. Types of FRCs used in dentistry. In: Vallitu P, Özcan M. Editor. A Clinical Guide to Principles of Fiber-Reinforced Composites in Dentistry. Duxford: Woodhead Publishing; 2011.p. 11-34. https://doi. org/10.1016/b978-0-08-100607-8.00002-2

[42] Gajewski VES, Pfeifer CS, Fróes-Salgado NRG, Boaro LCC, Braga RR Monomers used in resin composites: Degree of conversion, mechanical properties and water sorption/solubility. Braz Dent J 2012;23:508-14. http:// dx.doi.org/10.1590/S0103-64402012000500007

[43] Klapdohr S, Moszner N. New inorganic components for dental filling composites. Monatsh Chem 2005;136:21-45. https://doi.org/10.1007/s00706004-0254-y

[44] Ferracane JL. Resin composite - State of the art. Dent Mater 2011;27:29-38. https://doi.org/10.1016/j.dental.2010.10.020

[45] Giordano R. Materials for chairside CAD/CAM-produced restorations. J Am Dent Assoc 2006;137 Suppl:14S-21. https://doi.org/10.14219/jada. archive.2006.0397

[46] Lucsanszky IJR, Ruse ND. Fracture toughness, flexural strength, and flexural modulus of new CAD/CAM resin composite blocks. J Prosthdont 2020;29(1):34-41. https://doi.org/10.1111/jopr.13123

[47] Ilie N, Hickel R. Investigations on mechanical behavior of dental composites. Clin Oral Investig 2009;13:427-38. https://doi.org/10.1007/s00784-009-0258-4

[48] Kelly JR. Developing meaningful systematic review of CAD/CAM reconstructions and fiber-reinforced composites. Clin Oral Implants Res 2007;18 Suppl 3:205-17. https://doi.org/10.1111/j.1600-0501.2007.01443.x

[49] Horvath SD. Key parameters of hybrid materials for CAD/CAM-based restorative dentistry. Compend Contin Educ Dent 2016;37(9):638-43.

[50] Wang H, Cui B, Li J, Li S, Lin Y, Liu D, et al. Mechanical properties and biocompatibility of polymer infiltrated sodium aluminum silicate restorative composites. J Adv Ceram 2017;6(1):73-9. https://doi.org/10.1007/s40145-0160214-0

[51] Shofu Dental Corporation (Special Report). TRINIA ${ }^{\text {TM}}$ : The next generation of CAD/ CAM and metal-free restorations. Compend Contin Educ Dent 2016;37 (10):662.
[52] Takahashi Y, Chai J, Tan SC. Effect of water storage on the impact strength of three glass fiber-reinforced composites. Dent Mater 2006;22(3):291-7. https:// doi.org/10.1016/j.dental.2005.04.035

[53] Ewers R, Perpetuini P, MorganVJ, Marincola M, Wu R, Seemann R. TRINIA TM — Metal-free restorations. Implants 2017;18(1):22-7.

[54] Seemann R, Marincola M, Seay D, Perisanidis C, Barger N, Ewers R. Preliminary results of fixed, fiber-reinforced resin bridges on four $4-\times 5-\mathrm{mm}$ ultrashort implants in compromised bony sites: A pilot study. J Oral Maxillofac Surg 2014;73(4):630-40. https://doi.org/10.1016/j.joms.2014.10.031

[55] Bassi M, Bedini R, PecciR, Ioppolo P, Laritano D, Carinci F. Mechanical properties of abutments: resin-bonded glass fiber-reinforced versus titanium. Int J Prosthodont 2016;29(1):77-9. DOI: 10.11607/ijp.4169

[56] Lee JH, Kim HW, Seo SJ. Polymer-Ceramic Bionanocomposites for Dental Application. J Nanomater 2016;2016:8. http://dx.doi.org/10.1155/2016/3795976

[57] Hada T, Takahashi H, Kamijo S, Ikeda M, Kitamura T, Higuchi S, et al. Effect of CAD/CAM fabricated framework on complete denture deformation [abstract]. Dent Mater 2016;32 Suppl 1:24-5. https://doi.org/10.1016/j.dental.2016.08.048

[58] Nagayoshi M, FukuizumiT, Kitamura C, Yano J, Terashita M, Nishihara T. Efficacy of ozone on survival and permeability of oral microorganisms. Oral Microbiol Immunol 2004;19(4):240-6. https://doi.org/10.1111/i.1399302X.2004.00146.X

[59] Seemann R, Wagner F, Marincola M, Ewers R. Fixed, fiber-reinforced resin bridges on $5.0 \mathrm{~mm}$ implants in severely atrophic mandibles: up to 5-years follow-up of a prospective cohort study. J Oral Maxillofac Surg 2018;76(5):95662. https://doi.org/10.1016/j.joms.2017.11.043

[60] Spitznagel FA, Scholz KJ, Vach K, Gierthmuehlen PC. Monolithic polymerinfiltrated ceramic network CAD/CAM single crowns: three-years mild-term results of a prospective clinical study. Int J Prosthodont 2020;33(2):160-8. doi: $10.11607 /$ ijp. 6548

[61] Alamoush RA, Silikas N, Salim NA, Al-Nasrawi S, Satterthwaite JD. Effect of the composition of CAD/CAM composite blocks on mechanical properties. BioMed Res Internat 2018;2018:8 https://doi.org/10.1155/2018/4893143

[62] Spitznagel FA, Vuck A, Gierthmühlen PC, Blatz MB, Horvath SD. Adhesive bonding to hybrid materials: an overview of materials and recommendations. Compend Contin Educ Dent 2016;37(9):630-37.

[63] Koizumi H, Saiki O, Nogawa H, Hiraba H, Okazaki T, Matsumura T. Surface roughness and gloss of current CAD/CAM resin composites before and after toothbrush abrasion. Dent Mater J 2015;34(6):881-87. https://doi.org/10.4012/ dmj.2015-177

[64] Koller M, Arnetzl GV, Holly L, Arnetzl G. Lava ultimate resin nano ceramic for CAD/ CAM: customization case study. Int J Comput Dent 2012;15(2):159-64.

[65] Awada A, Nathanson D. Mechanical properties of resin-ceramic CAD/ CAM restorative materials. J Prosthet Dent 2015;114(4):587-93. https://doi. org/10.1016/j.prosdent.2015.04.016

[66] Cinar S, Altan B, Akgungor G. Comparison of bond strength of monolithic CAD-CAM materials to resin cement using different surface treatment methods. J Advan Oral Res 2019;10(2):120-7. https://doi.org/10.1177/2320206819862062

[67] Lawson NC, Bansal R, Burgess JO. Wear, strength, modulus and hardness of CAD/CAM restorative materials. Dent Mater 2016;32(11):e275-e83. https://doi. org/10.1016/i.dental.2016.08.222

[68] Jassim ZM, Majeed MA. Comparative evaluation of the fracture strength of monolithic crowns fabricated from different all-ceramic CAD/CAM materials (an in vitro study) Biomed Pharmacol J 2018;11(3):1689-97. http://dx.doi. org $/ 10.13005 / \mathrm{bpj} / 1538$

[69] Agarwalla SV, Malhotra R, Rosa V. Translucency, hardness and strength parameters of PMMA resin containing graphene-like material for CAD/CAM restorations. J Mech Behav Biomed Mater 2019;100:103388. https://doi. org/10.1016/j.jmbbm.2019.103388

[70] Takahashi H, Finger WJ, Endo T, Kanehira M, Koottathape N, Komatsu M et al. Comparative evaluation of mechanical characteristics of nanofiller containing resin composites. Am J Dent 2011;24(5):264-70.

[71] Lim K, Yap AU, Agarwalla SV, Tan KB, Rosa V. Reliability, failure probability, and strength of resin-based materials for CAD/CAM restorations. J Appl Oral Sci 2016;24(5):447-52. http://dx.doi.org/10.1590/1678-775720150561

[72] Egilmez F, Ergun G, Cekic-Nagas I, Vallittu PK, Lassila LVJ. Does artificial aging affect mechanical properties of CAD/CAM composite materials. J Prosth Res 2018;62(1):65-74. http://dx.doi.org/10.1016/j.jpor.2017.06.001

[73] Venturini A, Prochnow C, Pereira GKR, Segala RD, Kleverlaan CJ, Valandro LF. Fatigue performance of adhesively cemented glass-, hybrid- and resinceramic materials for $\mathrm{CAD} / \mathrm{CAM}$ monolithic restorations. Dent Mater 2019;35:534-42. doi: 10.1016/j.dental.2019.01.013

[74] Giertmuehlen P, Rübel A, Stampf S, Spitznagel F. Effect of reduced material thickness on fatigue behavior and failure load of monolithic CAD/CAM PICN molar crowns. Int J Prosthodont 2019;32:71-4 doi: 10.11607/ijp.5946

[75] Papadopoulos K, Pahinis K, Saltidou K, Dionysopoulos D, Tsitrou E. Evaluation of the surface characteristics of dental CAD/CAM materials after different surface treatments. Materials 2020;13(4):981. https://doi.org/10.3390/ ma13040981

[76] Tekçe N, Tuncer S, Demirci M, Kara D, Baydemir C. Microtensile bond strength of $\mathrm{CAD} / \mathrm{CAM}$ resin blocks to dual-cure adhesive cement: the effect of different sandblasting procedures. J Prosthodont 2019;28(2):e485-e490. doi: 10.1111/jopr.12737.

[77] Rosentritt M, Krifka S, Strasser T, Preis V. Fracture force of CAD/CAM resin composite crowns after in vitro aging. Clin Oral Invest 2019. https://doi. org/10.1007/s00784-019-03099-1. 
[78] Facenda JC, Borba M, Corazza PH. A literature review on the new polymerinfiltrated ceramic-network material (PICN). J Esthet Restor Dent 2018;30:281286. https://doi.org/10.1111/jerd.12370

[79] Spitznagel FA, Boldt J, Giertmuehlen PC. CAD/CAM ceramic restorative materials for natural teeth. J Dent Res 2018;97:1082-91. https://doi. org/10.1177/0022034518779759
[80] Schepke U, Meijer HJ, Vermeulen KM, Raghoebar GM, Cune MS. Clinical bonding of resin nano ceramic restorations to zirconia abutments: a case series within a randomized clinical trial. Clin Implant Dent Relat Res 2016;18(5):98492. https://doi.org/10.1111/cid.12382

[81] Tsitrou EA, Northeast SE, van Noort R. Brittleness index of machinable dental materials and its relation to the marginal chipping factor. J Dent 2007;35(12):897-902. https://doi.org/10.1016/j.jdent.2007.07.002 